DOI: $10.31168 / 2619-0842.2018 .11$

K. С. Задоя (Дюссельдорф), Е. Э. Будовская (Вашингтон)

\author{
РИТУАЛЬНЫЕ ДИАЛОГИ \\ В СВЯТОЧНОЙ ОБРЯДНОСТИ УКРАИНСКИХ КАРПАТ
}

\title{
ВВЕДЕНИЕ
}

Проблема реконструкции древнего праславянского текста, которая привлекала внимание многих исследователей-лингвистов и фольклористов, в том числе Н. С. Трубецкого, Р. О. Якобсона, Вяч. Вс. Иванова, В. Н. Топорова, В. Я. Проппа, заставила в свое время Н. И. Толстого обратить внимание на ритуальные тексты - в частности, ритуальные диалоги. Он считал ритуальный диалог эпизодом обрядового действия, имеющим трехчастную структуру: вопрос, ответ и следующий за ним комментарий первого участника. Кроме того, по Толстому, диалог имеет тенденцию повторяться трижды (СД 2: 88).

В своих работах (Толстой 1984; Толстой 1993) ученый собрал около 360 диалогов из разных традиций и разбил их на группы, взяв за основу вид сакрализованного действия, которое они сопровождали.

Самый древний славянский ритуальный диалог, упоминаемый Толстым, был зафиксирован в XII в. на острове Рюген средневековым датским хронистом Саксоном Грамматиком (Толстой 1984: 6-7), остальные тексты относятся к началу XIX - первой половине XX в. Судя по географии текстов/примеров, ритуальные диалоги известны всем славянским традициям. При этом сам Толстой и в вышеупомянутых работах, и в статье «Диалог-ритуал», написанной для этнолингвистического словаря «Славянские древности» (СД 2: 88-92), отмечал, что особенно хорошо ритуальные диалоги сохранились в сербской этнокультурной среде (почти половина приводимых им примеров), а также у болгар и македонцев.

Карпатская народная традиция, частично затронутая Толстым, также содержит большое количество ритуальных диалогов. Некоторые из них 
относятся к не описанным ранее типам. Большинство карпатских диалогов приурочено к обрядам святочного цикла.

В этой статье нас интересуют типы, структура и повторяющиеся элементы в карпатских святочных диалогах, записанных нами (К. 3.) за последние 30 лет. На наш взгляд, наличие элемента одновременно в нескольких географических точках — следствие не только его возможного происхождения из общего источника (выяснение временно́й глубины которого - отдельная задача), но и того, что по какой-то причине он оказался столь важным для носителей культуры, что не был забыт или вытеснен, а воспроизводился практически до настоящего времени. Следует отметить, что традиционный характер элемента сам по себе не является достаточным объяснением его сохранности. Несомненно, традиционная культура консервативна и резистентна к изменениям, особенно в области святочных обрядов, где носитель уверен, что точное выполнение обряда гарантирует ему благополучие на весь грядущий год. Однако факторы традиционности и важности для благополучия не обязательно обеспечивают сохранение обряда во всех его деталях; примером может служить карпатская сельская свадьба, которая за несколько десятков лет претерпела ряд радикальных изменений, впитав большое количество элементов из множества источников и потеряв некоторые элементы, которые ранее считались ключевыми. В нашем понимании, в культуре, организующей социум определенным образом, бо́льшую вероятность сохранения будут иметь элементы, подтверждающие эту организацию, то есть поддерживающие, например, гендерные, возрастные и другие ценности и установки данной культуры. С этой точки зрения мы и пытаемся подойти к карпатским святочным диалогам.

Основным материалом для настоящего исследования послужили записи этнолингвистических и фольклорных экспедиций 1987-2018 гг., сделанные К. С. Задоя во Львовской, Ивано-Франковской, Закарпатской и Черновицкой областях Украины. Материал записывался от информантов 1900-1945 гг. рождения. На настоящий момент обследовано 76 сел ${ }^{1}$.

Анализ записей показывает, что ритуальные диалоги являются неотьемлемой частью карпатского святочного обряда, поскольку, как правило,

Подробный перечень сел см., например: Задоя 2015; в 2017 г. было обследовано с. Боберка Турковского р-на Львовской обл., в 2018 г. — с. Жупаны и с. Лавочное Сколевского р-на Львовской обл. 
маркируют ключевые моменты обряда и представляют собой довольно устойчивый элемент святочного обрядового текста.

Святочные обрядовые диалоги можно разбить на две основные группы: одни направлены на приумножение достатка в семье (продуцирующая магия), другие - на защиту от возможного вреда (защитная магия).

\section{ПРОДУЦИРУЮЩАЯ МАГИЯ}

Диалоги, разыгрываемые на пороге дома перед праздничным ужсном в сочельник

Эти диалоги представляют собой самую многочисленную группу среди зафиксированных нами текстов. Когда в доме уже всё готово для святочного ужина и вся семья в сборе, глава семьи (как правило, хозяин) идет в хлев за соломой, отавой ${ }^{2}$ и рождественским снопом (наряду с хлебом, это основные святочные атрибуты в украинских Карпатах). Возвращаясь, хозяин останавливается у порога, и между ним и хозяйкой происходит диалог, после которого солома, отава и сноп заносятся в комнату. Примеры диалогов см. ниже.

По содержанию подобные диалоги представляют собой благопожелание. В них существуют определенные повторяющиеся элементы как словесные, так и акциональные. В таком диалоге, как правило, участвуют два персонажа - мужчина и женщина. Мужчина находится снаружи, у порога, женщина - внутри дома. Женщина задает один или несколько вопросов, мужчина отвечает. Женщина, иногда вместе с другими обитателями дома, отвечает благодарностью или закрепляет благопожелание, повторяя или истолковывая последнюю фразу, сказанную мужчиной. Ответив на последний вопрос, мужчина может благословить дом, желая его обитателям удачи и процветания.

Говоря о распределении ролей и пространственного положения между участниками, необходимо отметить, что тот, кто стоит снаружи и оттуда благословляет, - это всегда мужчина. Если вспомнить предположение В. Я. Проппа (Пропп 1995: 45-66) о том, что персонажи, совершающие зимние обходы, являются олицетворением духов предков, приносящих благословение с того света, то это хорошо отражено и в драматургии,

2 Сено второго укоса. 
и в содержании карпатских ритуальных диалогов. Как и в обрядах, описанных Проппом, мужчина, который находится у порога и благословляет хозяйство, согласно многим деталям в диалогах, изображается как пришедший издалека (см. ниже).

Во многих прикарпатских селах вопрос, задаваемый пришедшему, обращен к снопу, от имени которого отвечает хозяин. В этих случаях духом предков, благословляющим дом живущих, является сноп, что подтверждается и его названием дідо 'дед' 3.

с. Илемня, Рожнятовский р-н, Ивано-Франковская обл

Хозяин: - Добрий вечір!

Хозяйка: - Добрий вечір!

(повторяется 3 раза)

Хозяйка: - Вiдкі ви, діду?

Хозяин: - С підгір я!

Хозяйка: - Чого сь прийшов?

Хозяин: - Бо я з усіх сторон збираю полон, а до вас, убогих, іду вечеряти!

Хозяйка: - С богом!

Хозяин: - С богом!

[Хозяин проходит в дом, ставит сноп в угол, просит:]

$$
\text { - Дайте ложку! }
$$

и затыкает ее в сноп.

Вариант концовки (= приглашение) (зап. там же, Гутак Е. Н., 1919 г. р.): Хозяйка: - Просимо, сідайте! Даємо вам лежку, будете з нами вечеряти!
Хозяин: - Добрый вечер!

Хозяйка: - Добрый вечер!

Хозяйка: - Откуда вы, дідо?

Хозяин: - Из подгорья!

Хозяйка: - Зачем пришел?

Хозяин: - Потому что я со всех сторон собираю полон, а к вам, убогим, иду ужинать!

Хозяйка: - С богом!

Хозяин: - С богом!

- Дайте ложку!

Хозяйка: - Пожалуйста, садитесь! Даем вам ложку, будете с нами ужинать!

(Пелипив Е. С., 1928 г. р.; записано летом 2006 г.)

3 Большинство диалогов приводится только в виде реплик с русским переводом и ремарками на русском языке. В отдельных случаях рассказ информанта приводится полностью и сопровождается переводом. 
Приведенный выше пример из с. Илемня - это развернутый диалог, включающий много элементов, в том числе два вопроса и ответы на них. Во-первых, сноп спрашивают, откуда он и зачем пришел, а он отвечает, что «с подгорья» и «со всех сторон», то есть он много ходил и пришел издалека. Кроме того, в диалоге наличествует мотив полона, собранного пришедшим со всех сторон и обозначающего полноту или изобилие 4 . Наконец, пришедшего приглашают к столу (или он сам говорит, что будет ужинать с хозяевами). Таким образом, в диалоге присутствуют элементы благословения и вознаграждения благословляющего, отмеченные еще Проппом в ритуальных святочных текстах, колядках и щедровках.

Кроме этого, развернутый диалог включает вопрос(ы) и ответ(ы), а также подтверждение ответа и/или его истолкование как благопожелание на весь год. Трехчастная структура (вопрос — ответ - валидация правильности ответа) заставляет вспомнить другой жанр - загадку, в которой также присутствуют все три вышеупомянутых элемента. Это тем более релевантно для святочного диалога в свете открытия В. Н. Топоровым (Топоров 2004: 472) ритуального загадывания и разгадывания загадок в древнеиндийской традиции «на стыке Старого и Нового года» для воссоздания миропорядка на грядущий год; в этом ритуале «каждый правильный ответ как бы восстанавливает лакуну в космической организации и верифицирует подлинность нового состояния». Нечто аналогичное происходит и в карпатской традиции произнесения диалогов, где из дома задается вопрос, из-за порога звучит ритуальный правильный ответ, а из дома ответ верифицируется как благопожелание на весь наступающий год.

4 Слово «полон» в похожем значении малоизвестно в украинских говорах. В словаре Гринченко полон имеет значения 'плен; пленные; род насекомого'. Интересно, что в некоторых обследованных селах (Новошин) реплики этого диалога не рифмуются: з усі́x стороін $\mid-$ а шчó но́сите dídy | но́шу поло́н. Это заставляет предположить, что диалог может быть заимствован. Если учесть, что по-польски реплики рифмуются (ze wszystkich stron - plon), а plon стандартно значит 'урожай', то предположение о заимствованном характере (и последующей украинизации) диалога получает подтверждение. В пользу этого говорит и тот факт, что в ЕСУМ и в словаре Фасмера (Фасмер 2003) польский отмечен как единственный славянский язык, где рефлекс общеславянского *pelnъ имеет значение 'урожай', а не 'плен'. 
Разумеется, эти элементы не всегда присутствуют в полном составе, как, например, в первом из приводимой ниже пары диалогов, где есть вопрос и ответ, а также элементы «пришел издалека» и «принес полон», но нет (или не записано) элемента верификации, а также вознаграждения (приглашения к ужину). Во втором диалоге, однако, присутствуют все элементы, а также (в конце) христианское святочное приветствие-благопожелание, произносимое пришедшим опять-таки из-за порога:

с. Луквица, Богородчанский р-н, Ивано-Франковская обл.

Хозяин: - Добрий вечір!

Хозяйка: - Добрий вечір!

(повторяется 3 раза)

Хозяйка: - Де сь ходив?

Хозяин: - А я ходив збирати полон з усіх сторон, жито, пшенищю, вівса на кіселицюю, з гірї, з підгірі, на ваме подвірї!
Хозяин: - Добрый вечер!

Хозяйка: - Добрый вечер!

Хозяйка: - Где ты ходил?

Хозяин: - А я ходил собирать полон со всех сторон, жито, пшеницу, овес на киселицу, с горья, с подгорья, на ваш двор!

(Василив Н. В., 1933 г. р.; записано летом 2007 г.)

c. Новошин, Долинский p-н, Ивано-Франковская обл.

Хозяин: - Добрий вечір!

Хозяйка: - Дай боже здоровля! Відкі ходите, діду?

Хозяин: - 3 усіх сторін!

Хозяйка: - А щзо носите, дiдy?

Хозяин: - Ношу полон!

Хозяйка: - Дай боже би сте рік теперь щасливо носили!

Хозяин: - Христос ся раждає!
Хозяин: - Добрый вечер!

Хозяйка: - Дай боже здоровья! Откуда вы идете, дidy?

Хозяин: - Со всех сторон!

Хозяйка: - А что вы носите, дідy?

Хозяин: - Ношу полон!

Хозяйка: - Дай боже, чтобы и через год счастливо носили!

Хозяин: - Христос рождается!

(Кабинеи А. Ю., 1924 г. р.; записано летом 2005 г.)

За пределами Прикарпатья похожий диалог, включающий в себя вопрос, обращенный к $\partial i \partial y$, его ответ и валидацию ответа как благопожелания, 
был записан нами в бойковских селах Сколевского р-на Львовской обл. Завадка и Жупаны. Приводим диалог из Завадки:

c. Завадка, Сколевский р-н, Львовская обл.

(Диалог происходил в темноте, поскольку перед внесением снопа специально гасили свет.)

Хозяйка: - Шо носищ?

Хозяин: - Голову тямке́, як зо́лото!

(имеется в виду «голова» снопа, т. е. колосья, вверх которыми он ставился в угол)

Хозяйка: - Дай боже би носив яг рік від року!

После этих слов зажигали свечу, заносили солому и сноп и приступали к трапезе.

Хозяйка: - Что ты носишь?

Хозяин: - Голову, тяжелую, как золото!

Хозяйка: - Дай боже, чтобы ты носил каждый год!

(Игнатович А. М., 1937 г. р.; записано летом 2004 г.)

Интересно, что в Завадке, как и в Жупанах, сноп заносят в полной темноте, что отмечают все информанты. Это может служить дополнительным указанием на потустороннюю природу благословляющего духа предков. В других диалогах из Завадки вопроса к снопу нет, приветственная реплика, произносимая хозяином, включает в себя и приветствие, и пожелание благополучия одновременно, а ответная реплика произносится не хозяйкой, а всеми членами семьи:

\begin{tabular}{|c|c|c|c|}
\hline \multirow[t]{2}{*}{ Хозяин: } & - Добрый вечір! & \multirow[t]{2}{*}{ Хозяин: } & - Добрый вечер! \\
\hline & $\begin{array}{l}\text { Дай боже тоті свята } \\
\text { щасливо відпровадити, } \\
\text { других дочекати! }\end{array}$ & & $\begin{array}{l}\text { Дай боже эти } \\
\text { праздники счастливо } \\
\text { провести и других } \\
\text { дождаться! }\end{array}$ \\
\hline омац & Дай боже! & Дома & - Дай боже! \\
\hline
\end{tabular}

(Марочканич А. Ю., 1935 г. р.; записано летом 2004 г.) 
Хозяин: - Дай боже щастя із святим вечіром!

Дай боже ті свята упровадити, других дочекати всім людям і нам по при люди!

Домашние: - Дай господи!
Хозяин: - Дай боже счастья с сочельником! Дай боже эти праздники проводить, других дождаться, всем людям и нам при людях!
Домашние: - Дай господи!

(Русина Я. Д., 1944 г. р.; записано летом 2004 г.)

\begin{tabular}{l|ll} 
Хозяин: & Хозяин: & - Дай боже щастя боже счастья \\
з геречуно́м! & с геречуно́м! \\
Христос ся рождає! & Христос рождается! \\
Дай боже ті свята & Дай боже эти \\
упровадити, других & праздники \\
дочекати всім людям & проводить, других \\
і нам по при люди! & дождаться, всем \\
& людям \\
Домашние: - Дай боже! & и нам при людях!
\end{tabular}

(Марочканич Т. Н., 1930 г. р.; записано летом 2004 г.)

Диалоги подобного типа (в которых отсутствует собственно вопросно-ответная часть) с той же обрядовой приуроченностью встречались нам и в Прикарпатье, и у бойков Львовской области. Как правило, они включают благопожелание и ответ на него домашних, а приветствие домашних и, главное, вопрос к пришедшему в них отсутствуют:

с. Грабовеи, Богородчанский р-н, Ивано-Франковская обл.

Хозяин заносит сноп (дida) и произносит благопожелание (вінчує):

- Вінчую вас счастем, здоров 'єм, сим Святим вечіром, аби сте сей Світий вечір щзасливо опрова́дили, другого дочекали,
- Желаю вам счастья, здоровья этим святым вечером, чтобы вы этот святой вечер счастливо провели, другого дождались, 
рік від року,

до нового року,

до сто літ,

покі па́н біг продовже́т вік!

Христос ся рождає!

Домашние отвечают:

- Слава Ісусу Христу! каждый год,

до нового года,

до ста лет,

пока Господь продолжает век!

Христос рождается!

- Слава Иисусу Христу!

(Важейска С. М., 1926 г. р.; записано летом 2007 г.)

с. Ямельница, Сколевский р-н, Львовская обл.

Хозяин заносит 2 снопа, солому и отаву (сено второго укоса):

- Дай боже добрий вечір, дай боже щзасливі света, тоті упоредкувати та других дочекати!

Хозяйка в ответ:

- Дай боже!
- Дай боже добрый вечер, дай боже счастливые праздники, эти провести в порядке и других дождаться!

- Дай боже!

(Яичкив А. Д., 1913 г. р.; записано летом 2004 г.)

Однако отсутствие вопросно-ответной части выводит такие диалоги за скобки ритуальных диалогов, несмотря на обрядовую приуроченность и состав участников.

В большинстве закарпатских сел ритуальных диалогов с вопросами и ответами нет. Подавляющее большинство текстов, произносимых хозяином и хозяйкой при внесении соломы и снопа, зафиксированных нами на Закарпатье, представляют собой обмен праздничными приветствиями (Христос рождаєся! - Славім його! / Дай боже добрий (щасливий) Сятый вечур! - Дай боже здоровля! и т. п.).

На Закарпатье существует и другой вариант диалога. Он записан в Великоберезнянском районе, то есть на крайнем западе Закарпатья, граничащем со Словакией, в селе Смереково. Здесь после приветствия женщина задает входящему вопрос, касающийся погоды, и истолковывает полученный 
ответ как благопожелание или благословление урожая. Здесь тоже имеются все три ключевых элемента: вопрос - ответ - истолкование / закрепление ответа как благопожелания. Этот вариант диалога записан нами всего в одном селе, но от многих информантов, что показывает неслучайность его бытования. Приведем здесь два варианта этого диалога:

Хозяин, занося солому и сноп:

- Дай боже щасливий Сятый вечур!

Хозяйка: - Як на небі?

Хозяин: - Ясно!

Хозяйка: - На нашій землі рясно!

(Пояснение информантки: так

вінчувуть, чтобы родился хлеб.)

— Дай боже счастливый сочельник!

Хозяйка: - Как на небе?

Хозяин: - Ясно!

Хозяйка: - На нашей земле густо!

[в оригинале вопрос и ответ рифмуются]

(Кичера О. Ю., 1910 г. р.; записано летом 1991 г.)

Хозяин: - Дай боже добрий вечур!

Хозяйка: - Дай боже здоровля! Як на небі?

Хозяин: - Ясно!

Хозяйка: - Так би на наших землях рясно!

(диалог повторялся трижды)
Хозяин: - Дай боже добрый вечер!

Хозяйка: - Дай боже здоровья! Как на небе?

Хозяин: - Ясно!

Хозяйка: - Так бы и на наших землях густо!

[в оригинале вопрос и ответ рифмуются]

(Попадыч В. В., 1919 г. р.; записано летом 1991 г.)

\section{Диалоги, содержащче угрозы плодовым деревьям}

Это следующая по многочисленности группа ритуальных диалогов. Они зафиксированы в 36 из 76 обследованных сел, в остальных селах нам встречались многочисленные рассказы о том, что существовал обычай «пугать» плодовые деревья - замахиваться или слегка ударять топором по стволу неплодоносящего дерева, но никаких диалогов или приговоров при этом не произносилось.

Диалоги-угрозы приурочены к разным дням святочного цикла. Общая их структура такова: диалог исполняется мужчиной и женщиной, чаще 
всего одного возраста (баба и дед, хозяин и хозяйка, брат и сестра, реже - отец и дочь); мужчина замахивается на дерево топором и обещает срубить его, если оно не будет родить («Рубаю тя, коли не родишь!», «Родь, або тя зріжу!» и т. п.); женщина отвечает за дерево и просит не рубить себя, обещая родить. Как правило, диалог произносился трижды.

Приведем здесь самые интересные, на наш взгляд, примеры диалогов:

с. Битля, Турковский р-н, Львовская обл.

(Идут брат с сестрой, брат несет топор.)

Брат: - Pyn-nópyn! Куда у́тну - пере́тну!

Сестра: - Братчику, не рубай! Вна нам буде яблика родити!

Брат: - Руп-по́руп! Куда рубану — перерублю!

Сестра: - Братец, не руби! Она нам будет яблоки родить!

(Колищак М. И., 1910 г. р.; записано летом 1989 г.)

с. Синевирская Поляна, Межгорский р-н, Закарпатская обл.

(Идут муж и жена, он несет топор, она - солому.)

Муж: - Рубаю тя!

Муж: - Срублю тебя!

Жена: - Не рубай, бо буду родити!

Жена: - Не руби, буду родить!

(Произносят трижды, после чего женщина обвязывает ствол дерева принесенной соломой.)

(Пидберецька Г. П., 1906 г. р.; записано летом 1989 г.)

с. Ярок, Ужгородский р-н, Закарпатская обл.

(Идут муж и жена, он несет топор, она - солому.)

Муж: - Будеш родити?

Жена: - Та й буду!

Муж: - Бо як не будеш родити, зрубаю тя!

Муж: - Будешь родить?

Жена: - Да буду!

Муж: - Потому что если не будешь родить, срублю тебя!

После этого делают из соломы венок и обвязывают ствол дерева.

(Ш. М., 1919 г. р.; записано летом 1988 г.) 
Существуют менее развернутые варианты этого обряда, когда отсутствует собственно диалог. Например, в ряде сел это действие целиком исполнялось хозяином в одиночку (замахиваясь, он произносил приговор-угрозу). В некоторых селах первый участник ритуала замахивался топором, но не произносил при этом никаких словесных угроз, угрозу представляло само действие. Во многих селах все перечисленные варианты существовали параллельно.

Интересно, что в диалогах, когда мужчина угрожает дереву, женщина может не только защищать дерево, но и говорить от его лица. Отождествление фруктового дерева и женщины проявляется также в других обрядах в Карпатах (так, вода, в которой гасили угольки от дурного глаза, выливается на яблоню, грушу или сливу, если лечат девочку, и на бук или дуб, если лечат мальчика ${ }^{5}$ ). В данном типе святочных диалогов мужчина, скорее всего, не олицетворяет духа предков; духом, причем духом дерева, является женщина, а мужчина пугает ее и заставляет родить под угрозой уничтожения. В патриархальной культуре Карпат ${ }^{6}$ такой расклад сил подтверждает гендерные стереотипы; не исключено, что вследствие этого данный тип диалога является таким распространенным.

\section{Диалоги, произносимые во время ритуального прятания за святочным хлебом}

В селе Лазещина Раховского р-на Закарпатской области нами был зафиксирован обычай «прятания» за хлебом, подобный тому, который наблюдал в XII в. Саксон Грамматик на острове Рюген ${ }^{7}$.

В сочельник перед трапезой на стол складывали весь имеющийся в доме хлеб - так, чтобы получилась «гора на полстола». Хозяин вставал по одну сторону стола, хозяйка - по другую, и между ними происходил следующий диалог:

5 Новоселица Межгорского р-на Закарпатской обл., запись Е. Будовской в 2013 г. от женщины 1940 г. p.

6 См.: Будовская, Задоя (в печати).

7 Толстой 1984: 12 упоминает аналогичный обряд в Карпатах, у лемков Горлицкого повята, а также у гуцулов, но приуроченный к Пасхе, а не к Рождеству. 
$[\ldots]$ діду $\mid$ ти мене ведиш $\mid$ а дідо кає | ні |аби бог дав бим ті більщи на гід не веділа | $[\ldots]$ «Дед, ты меня видишь?» А дед говорит: «Нет!»— «Дай бог, чтобы я тебя через год не больше видела!»

(Передарюк М. И., 1919 г. р.; записано летом 1993 г.)

[...] бапко | ці ти мене ведии $\mid$ ні | бапко | бог дав абим т'е на гід $i$ тілько не ведів |
[...] «Бабка, видишь ты меня?»«Нет!»— «Бабка, пусть бог даст, чтобы я тебя через год даже настолько не увидел!»

(Звиздарюк М. И., 1918 г. р.; записано летом 1993 г.)

Делалось это для того, чтобы в доме не переводился хлеб и чтобы на следующий год его было еще больше.

Два вышеприведенных отрывка записаны от разных информантов, поэтому не очень понятно, как распределены гендерные роли. Тем не менее оба диалога свидетельствуют о том, что вопрос может задаваться мужем жене, а также, симметрично, женой мужу, когда они оба находятся в пространстве дома. В этом свете интересна запись Шейна из Полесья ${ }^{8}$, где муж и жена также благословляли друг друга - и где хорошо отражена идея разной гендерной принадлежности разных сфер и элементов хозяйства.

Информант 1909 г. р., Тулайдан Ю. И., рассказывал, что обычай прятаться за хлебом появился в Лазещине вместе с приходом переселенцев «из-за перевала», то есть со стороны Прикарпатья, одним из которых был его дед:

8 «В Мозырском Полесье в с. Кочищи (ныне Ельского района) более века тому назад был записан ритуал, исполнявшийся в Сочельник, по которому после ужина все отходили от стола и хозяин, перекрестившись трижды, садился в красном углу (на покуци), а его жена - хозяйка садилась напротив и спрашивала: Чи бачиш ты мене? (Видишь ли ты меня?) На это хозяин отвечал: Не бачу! Хозяйка заключала: Каб же ты не бачіў за стогами, за копами, за возами, за снопами свету! Затем хозяин спрашивал у жены: Бабо! Чи бачишь ты мене? Хозяйка отвечала: Не бачу! и хозяин заключал: Каб же ты не бачила за гурками, за гарбузами, за капустою, за бураками свету!» (Толстой 1984: 11 со ссылкой на Шейна). 
[...] ранше там $\mid$ туди $\mid$ за перевалум | як верьховена | а там такі такій звик був $\mid$ так'е ворожен'н'е | уже у всечір на с'етий вечір накладут товпу хліба так $\mid$ на півстола $\mid$ так високо | стої | но... | тай уже йдс няньо там або мама а туди є діти | тай стає поза тото $\mid$ та кає | ці мні | кає | видете $\mid$ кає |дітонькі | йой кає |мало вас $\mid$ кає $\mid$ ведемо $\mid$ но $\mid$ на другий рік аби сте і тілько мн'е не веділи | на другий рік аби шче май було більше хліба |
[...] Раньше там — туда, за перевалом, где Верховина, а там такой обычай был, такая ворожба. Вечером в сочельник накладут гору хлеба так, на полстола, так высоко, стоит, ну... И уже идет папа там или мама, а с другой стороны дети. Встает за этой [горой хлеба] и говорит: вы меня, говорит, видите, говорит, деточки? - Ой, - говорят, плохо вас, говорят, видим. - Ну вот, на следующий год чтобы вы и так меня не видели. [То есть,] на другой год чтобы еще больше было хлеба.

\section{Диалоги, исполнявшиеся при совершении магии, направленной на надой молока}

В с. Смольная Дрогобычского р-на Львовской обл. существовал обычай вечером накануне Крещения (здесь - Щедрий вечір) трижды обходить дом и хлев ${ }^{9}$ с хлебом и медом. Совершая обход, хозяин останавливался на каждом углу, окропляя его водой. При этом хозяйка, находившаяся в доме, всякий раз спрашивала через окно: «Що там несеш?» Хозяин отвечал: «Хліб, сметану!» Делалось это для того, чтобы корова весь год хорошо доилась, давала много молока.

Подобный диалог разыгрывался в Смольной и на Введение (21.XI/4. XII), во время аналогичного обхода, который совершался рано утром; только вместо хлеба и меда хозяин нес на плече кіселицую (кисель из овсяной муки), а на вопрос хозяйки «Що там, діду, несеш?» отвечал: «Сметану!»

\section{Диалоги про кур}

В ряде святочных диалогов, записанных нами в разных регионах Украинских Карпат, речь идет о курах. Так, в с. Новоселица Перечинского р-на

9 Раньше оба помещения располагались в так называемой однорядной постройке под одной крышей — подробнее см.: Будзан 1983: 161-162. 
Закарпатской обл. в сочельник перед трапезой мальчик бежит на двор, встает под окном и спрашивает у хозяйки: «А ичі дома наши кури?» Хозяйка отвечает: «Наши кури дома суть $і$ дома ся несуть!» ${ }^{10}$. Аналогичный диалог был записан нами и в Прикарпатье - в с. Дебеславцы Коломыйского р-на Ивано-Франковской обл. В с. Великая Линина Старосамборского р-на Львовской обл. стоящий под окном мальчик спрашивал: «B вас кури суm?» Хозяйка отвечала: «Cym, суm!», после чего мальчик высказывал пожелание: «Та нехай вам ся цілий рік несут!» ${ }^{11}$. Делалось это для того, чтобы куры хорошо неслись в течение года и не разбегались по чужим дворам.

Обращает на себя внимание то, что в большинстве таких диалогов обычная структура (вопрос из дома - ответ снаружи - истолкование из дома) является перевернутой: вопрос задает мальчик, стоящий за окном, ответ звучит из дома, после чего мальчик снаружи высказывает благопожелание. Только в одном диалоге женщина из дома дает ответ, который оказывается и благопожеланием.

Интересно, что если ранее рассмотренный нами диалог со снопом происходит у порога, то данный диалог происходит через окно, которое тоже является символической границей между мирами. Однако при этом мальчик находится на дворе, с внешней стороны окна, то есть олицетворяет внешние силы, видимо по причине своей гендерной принадлежности. При всей многочисленности вариантов диалогов, нам не известен ни один диалог с обратной пространственной расстановкой участников, то есть где бы женщина находилась вне жилого пространства, а мужчина (или мальчик) - внутри. Принадлежность женщины к пространству внутри дома подчеркивается в вышеприведенном диалоге из с. Новоселица Перечинского р-на и тем, что она произносит слова, магически привязывающие кур к дому.

В с. Новоселица Межгорского р-на Закарпатской обл. диалог, посвященный курам, произносился в тот момент, когда в дом заносили діда:

10 «Дома ли наши куры?» — «Наши куры дома и несутся дома!» (в оригинале ответ рифмуется).

11 «У вас есть куры?» — «Есть, есть!» — «Так пусть у вас целый год несутся!» (в оригинале вопрос и ответ рифмуются). 
[...] на святий вечір кажут | шо як несут діда до хати $\mid$ кажут $\mid$ ци фсі кури з яйцема $\mid$ кажут $\mid$ усі $\boldsymbol{\epsilon} \mid$ фсі $\boldsymbol{\epsilon} \mid$ най си несут $\mid$ як мачкоу трясут $\mid$
[...] В сочельник говорят, что когда заносят в дом дida, то спрашивают: «Все ли куры с яйцами?» Отвечают: «Все, все!» - «Пусть несутся, как кошкой трясут (!)»

(Славуник М. М., 1906 г. р.; записано летом 1989 г.)

К сожалению, в цитируемом интервью 1989 г. отсутствуют указания на половозрастную принадлежность участников ритуального диалога, но можно предположить, что вопрос и благопожелание произносит тот, кто заносит сноп, то есть хозяин.

В с. Горонда Мукачевского р-на Закарпатской обл. существовал обычай пытати кури (щупать кур), практиковавшийся в сочельник для того, чтобы куры хорошо неслись. Две женщины шли в курятник, одна поочередно брала в руки каждую курицу, другая задавала вопросы:

[...] єдна питат $\mid$ а друга вітповідає

| $з$ яйцьом $\mid$ яйцьом $\mid$ яйцьом |

зйцьом | так усі кури перепитат

| а піт кінеиь звідавут $\mid$ а когут $\mid$

з двума |
[...] Одна щупает, а другая отвечает: «С яйцом?» — «С яйцом!»«С яйцом?» - «С яйцом!». Так всех кур перещупают, а под конец спрашивают: «А петух?»— «С двумя!».

(Кучинка М. И., 1911 г. р.; записано зимой 1992 г.)

Здесь как вопрос, так и ответ произносится женщинами (об их статусе трудно сказать что-либо определенное - возможно, он и различался, если участницами диалога были, например, свекровь и невестка, но информантка об этом не упоминает). Во время диалога обе женщины находятся в одном пространстве (хлев) и, насколько можно судить, не разделены никакой преградой.

Диалоги, произносимые во время символического сбора грибов

В с. Поляница Долинского р-на Ивано-Франковской обл. в сочельник после трапезы дети бегут на то место во дворе, где колют дрова, и собирают тріски (щепки). Один собирает, другой задает вопрос: «Що ти збираєш?» Собирающий отвечает: «Гриби!» 
Похожие диалоги или отдельные фразы ищущих воображаемые грибы детей записаны нами также во многих селах Межгорского, Свалявского и Воловецкого районов Закарпатской обл. Подобный диалог был записан П. Г. Богатыревым в с. Прислоп Межгорского р-на Закарпатской обл. в 1930-х гг.; запись, сделанная на чешском языке, находится в фонде Богатырева в Российском государственном архиве литературы и искусства (РГАЛИ) в Москве (РГАЛИ. Ф. 47. ОП. 1. Ед. хр. 34. Л. 137):

Chlapci nebo divky jdou na dvưr, a jeden postavi na jednim konci, druhý na druhém. Jeden se ptá: "Kdo tu?" — "Já” odpovídá druhý. "Rostou houby?" - "Rostou”. Tak se mohou v tom roce najit houby.

Oba chlapci maji hůl. S holi tak pohybuji, jakoby hledali houby.
Мальчики или девочки идут во двор, один встает на одном конце, другой — на другом. Один спрашивает: «Кто тут?» — «Я», отвечает другой. «Растут грибы?»«Растут». Таким образом, в этом году они могут найти грибы. У обоих мальчиков есть палка. Они водят палками так, будто ищут грибы.

(информант не указан, запись 1930 г.)

Ритуальные диалоги между детьми интересны тем, что оба участника диалога - спрашивающий и отвечающий - обладают одним и тем же статусом. Кроме того, следует отметить: судя по тому, что в этих диалогах участвуют только дети, данная область хозяйства - собирательство в то время, когда складывались диалоги, была закреплена за детьми. Более широко распространена практика, когда те же святочные манипуляции, направленные на достижение того же эффекта, осуществлялись не в форме диалога, а в форме театрализации без закрепленных текстов (дети имитируют поиск, шаря палочкой в соломе под столом, - ищут грибы, а иногда орехи), но тем не менее участниками действия остаются исключительно дети.

\section{Ритуальный диалог с водой}

В с. Лазещина Раховского р-на Закарпатской обл. от информантки 1919 г. р. был записан диалог, исполнявшийся во время ритуального хождения по воду утром на Новый год. 
Хозяйка брала с собой хлеб и соль и шла к реке. Прежде чем зачерпнуть воды, она произносила следующий диалог, исполняя роль сразу двух персонажей - себя самой и воды:

Хозяйка:

- Добрыйдень, воде́иі-ярдари́ще!

Вода:

- Добре здорові, Марійко!

Хозяйка:

- Я даю тобі хліб, сіль, а ти мені дай здоров'є, щүісьие, довгий вік!
Хозяйка:

- Добрый день, водица-ярдари́uฺ!

Вода:

- Доброе здоровье, Марийка!

Хозяйка:

- Я даю тебе хлеб, соль, а ты мне дай здоровье, счастье, долгий век!

(Передарюк М. И., 1919 г. р.; записано летом 1993 г.)

После этого хозяйка отщипывала понемногу с трех сторон хлеба, бросала кусочки хлеба и соль в прорубь, набирала воды и возвращалась домой.

Похожие обращения к воде мы записывали в селах Завадка и Ямельница Сколевского р-на Львовской обл., Пилипец и Новоселица Межгорского р-на Закарпатской обл. и в самой Лазещине, но не в виде диалога, а в виде приговора, произносимого при ритуальном новогоднем омовении в реке. Поскольку диалог с обращением к воде не содержит вопросно-ответной пары, не исключено, что он имеет иное происхождение, нежели упомянутые ранее диалоги, а учитывая то, что чаще он встречается в виде приговора, возможно, что он вторичен и действительно представляет собой диалогизированный приговор.

\section{ЗАЩИТНАЯ МАГИЯ}

Диалоги, произносимье для защиты от недоброжелателей

В с. Завадка в сочельник в самом конце ужина один из членов семьи брал камень и трижды говорил: «Кусай!» Ему трижды отвечали: «Не можу!» После третьего раза говорящий произносил: «Так би на нас вороги не могли рот відкрити!» Затем камень клали под стол, где он лежал до конца святок. 


\section{Диалоги, произносимые при лечении и заговаривании болезней}

В с. Битля Турковского р-на Львовской области нами записан рассказ о том, что для того, чтобы ребенка не сглазили, в рождественский сочельник было принято плести веревочку и повязывать ребенку на шею. Веревочку, особенно красного цвета, часто используют в карпатской традиции для защиты от дурного глаза. Однако текст из Битли свидетельствует о том, что плетение веревочки, для большей действенности, могло не только приурочиваться к святкам, но и сопровождаться диалогом ${ }^{12}$.

МК: на сьвятвій ве̂́чірь | там dído | іс ба́боิв або ба́тько з матіро̂ | та сука́ли т [а]ки́й мотузо́к | і через nôpíx | єдно́ в ха́mi а дру́zе та́м | в на́с каза́ли в сінььо | бо вера́ньдів коли́сь не було а сіни | у сі́ньох так через два́ поро́zы сука́ли $\mid i$ зьві́дує ся $\mid$ то́ шо на дворрі́ $\mid y$ cíньох $\mid$ ка́же | но шо́ то су́чеш | кае́ від уро́ків | шобы о́ діти́на уро́ків не ма́ла $\mid$ i су́чут і то́ вже на свять́ій ве̂́чір $\mid$ як су́чут $i \mid$ môzдb́ на сьвятьій ве̂́чірь як су́чy_на сятьі́й ве̂́чірь | і привя́жут | діти́ні до ши́йки | та тоноййке сука́ли | но то каза́ли мотузо́к | привя́жуд_на шиию $\mid$ як | та́к шо | $і$ бува́ло шчо | й діти́ну | хто бу́дь урече́ | таке́ яке́сь бу́ло ичи краси́ве ции | ичи пога́не я́ с[а]ма́ не зна́ю | $і$ то́ | $і$ то́ ни́тка уже́ то пла... помага́ла | і то́ | просто рі́к та́м ичи ді́dо з ба́боิв | ции та́mо з ма́моิв | тó від уроิ́ків | на сьвятый ве̂́чірь $i \mid$ i mó від уроิків биіло шо помага́m
МК: На святой вечер, там дед с бабой, или отец с матерью, так они сучили такую веревочку, через порог, один в доме, а другой в... $\mathrm{У}$ нас говорили «в сенях», потому что веранд раньше не было, были сени. В сенях, так через два порога сучили. И спрашивает тот, кто на дворе, в сенях, говорит - а что ты сучишь? - От сглазу, говорит [другой], чтобы ребенка не сглазили. И сучат, это уже на святой вечер, как сучат, тогда на святой вечер.... Когда сучат, на святой вечер, а потом привяжут ребенку на шейку, такую тоненькую сучили.. говорили, веревочку, привяжут на шею, и если... бывало, что и ребенка сглазят, такой ребенок был или красивый, или плохой, я сама не знаю... и это... и эта нитка уже помогала. И это... просто год... или дед с бабой, или отец с мамой... это от сглазу, на святой вечер, и... это от сглазу было, помогало.

12 МК - Колищак М. И., 1910 г. р., КЗ - собирательница. Запись 1989 г. 
КЗ: а то́ не бъіло ния́кӧі різни́ці де́ хто́ стоя́в?

$\mathrm{MK}: я \tau_{-} \dot{я} \kappa ?$

К3: де́ хто сто́йит то немал/ло ния́коิї різнйці чи | жі́нка напрі́клад жїньйі

МК: ага́ шо | хто́́сь слу́хав шчо вони́ .... $\mid$ нье́ | не бъ்́ ${ }^{\circ} л$ | то вони́ соิбi там сука́ли по ти́ху ся .... від уро́ків i потоймy | привяза́ли дітїні на шеи́йу $i \mid$ і воно́ с ты́мм ходи́ло $\mid$ i што гли́пну на то́ | мотузо́к но уже́ | на мотузо́к поди́ви ся а уро́ки уже́|не|не достава́ло |
К3: А не было никакой разницы, где кто стоял?

МК: Что-что?

КЗ: Где кто стоит, не имело никакой разницы, или?.. Женщина например, женщине...

МК: а, что... слушал ли кто-то, что они... нет, не было такого, они себе там сучили тихонько и... от сглаза и потом... завязали ребенку на шейку и ребенок с этим ходил, и если посмотрят на это... на веревочку, то уже... на веревочку посмотрит, а сглазу уже... не было.

Интересно, что мотив плетения веревки через порог и избавления таким образом от нечистой силы нередко фигурирует в карпатских быличках о посещении упыря или путника ${ }^{13}$ : нечистую силу просят помочь свить веревку, а когда мифическое существо, держа другой конец веревки, выходит за порог дома, дверь захлопывают. Рассказчица указала на то, что в процессе плетения участвуют двое - мужчина и женщина, причем старшая пара в семье, но не уточнила, кто именно оставался в доме, а кто находился за порогами. Однако из рассказа мы узнаём, что задает вопросы тот, кто находится на дворе, что не вполне характерно для вопросно-ответной структуры святочных диалогов. С другой стороны, нахождение на дворе, вне пространства человеческого жилья, характерно для пришельца с того света, и это делает параллель с вышеупомянутым мотивом карпатских быличек еще очевидней. Интересно также, что, неправильно поняв вопрос о том, где находились участники диалога, информантка объясняет еще одну вещь, известную по заговорам и другим формам целительства магией ${ }^{14}$ : плетение веревочки должно было происходить тихо, и диалог

13 В карпатской народной мифологии - злой дух, проникающий в дом, где не закрыта дверь.

14 Например, заклинание от укуса змеи, приговор при гашении углей от сглаза и др. также произносились очень тихо - так, чтобы не слышал даже пациент. 
никто не должен был подслушать. Судя по большому количеству элементов, нетипичных для святочного диалога, но известных в других областях ритуальной жизни, этот диалог, скорее всего, является вторичным, появившимся в результате распространения практики святочного диалога на всё большее количество сфер человеческого бытия с целью получения прочного благополучия во всех сферах в наступающем году.

Диалоги, произносимые для изгнания мышей, крыс, тараканов, клопов и т. $n$.

Довольно часто эти диалоги являлись продолжением диалогов, произносимых при обходе дома со снопом или при занесении снопа. Видимо, сноп обладал такой магической силой, которая была способна не только принести в дом богатство и достаток, но и прогнать разную нечисть.

Так, в с. Красное Рожнятовского р-на Ивано-Франковской обл. в сочельник самый старший мужчина в семье брал сноп, втыкал в него серп, брал косу и трижды обходил дом, останавливаясь на углах и слегка ударяя по ним косой, - чтобы всё дурное держалось подальше от дома. Затем сноп, вместе с серпом и косой, заносился в дом:

[...] вже йде до хати тай каже $\mid[\ldots]$ | добрий вечір | а с чим ви дідо йдете | добрий вечір | що дідо несете | несемо все добро $\mid$ жсито $\mid$ пшеницю | усяку пашницю | а він вже тод $i$ відповідає $\mid$ шчо будемо їсти $\mid$ вже ми кажемо $\mid$ пшеницю $\mid$ а меши отаківо | тоті вже будут їсти самі себе | $[\ldots]$ уже заходит в дом и говорит:

$[\ldots]$ «Добрый вечер!» — «А с чем вы, дідо, идете?» — «Добрый вечер!»«Что, дідо, несете?»— «Несем всё добро - жито, пшеницу, всё, что растет в поле!» А он уже тогда отвечает: «Что будем есть?» А мы уже говорим: «Пшеницу!» — «А мыши?» — и всякое такое. «А они уже будут есть сами себя!»

(Гашук О. И., 1930 г. р.; записано летом 2006 г.)

В с. Ясиня Раховского р-на Закарпатской обл. хозяин, завершив обход, заходил со снопом и медом в дом и, стоя у порога, трижды обменивался приветствиями с хозяйкой, а затем приказывал тараканам, крысам и мышам покинуть дом, потому что в дом идет дідо: 
[...] вже як маємо вечеряти сідати | чоловік бере той міт | бере той сніп | $і$ опходит навколо хату | заходит у хату | уклон'еїсі | добрий вечір | три рази кажи так | а я вітповідаю жже $\mid$ г говорит $\mid$ стоїт коло порога i говорит $\mid$ коргани $\mid$ повх'е $\mid$ ичури $\mid$ меши | усё таке шитк'е | усі с хати | бо дідо йде у xamy | так три рази говорит | а тогди кладе діда в кут коло лушка $\mid$ i той дідо стоїт до йордану|
[...] уже как собираемся садиться ужинать, муж берет тот мед, тот сноп и обходит вокруг дома. Заходит в дом, здоровается: «Добрый вечер!» Три раза так говорит, а я уже отвечаю. И говорит - стоит около порога и говорит: «Тараканы, полевки, крысы, мыши, — всё такое, — всё из дома, потому что дiдо идет в дом!» Так три раза говорит, а затем кладет дida в угол около постели, и тот дідо стоит до самого Крещения.

(Логатчук Д. П., 1945 г. р.; записано летом 2007 г.)

В с. Быстрица Надворнянского р-на хозяин брал сноп, чистое полотенце, которым никогда не пользовались, и специальный хлеб, который затем на протяжении святок стоял на столе и в который втыкали свечку. На сноп ставили мисочку с пшеницей и мед, хозяин обходил хату, жена стояла внутри, около окна, и между ними происходил следующий диалог:

[...] він опходит хату | іде під вікно $\mid i$ каже їй $\mid$ добрий вечір $\mid$ вна вітповідає | добре здоровле | ичось варила | [...] вна вітповідає | я приготовила пшеницю |міт $\mid$ сіль $\mid$ і усяке добро | і вино $\mid$ а шчо буде їсти $\mid$ мити ну і таке нечисте | а сами себе тай с хати лісти |
[...] Он обходит дом, идет под окно и говорит ей: «Добрый вечер!» Она отвечает: «Доброго здоровья!» «Что варила?» Она отвечает: «Я приготовила пшеницу, мед, соль, всякое добро и вино». — «А что будут есть?» - мыши, ну и такое, нечистое. «А [будут есть] самих себя и [будут] уходить из дома!»

(Яремчук М. И., 1920 г. р.; записано летом 2007 г.)

После этого хозяин еще раз обходил дом, снова останавливался под окном и задавал хозяйке те же вопросы, получая те же ответы. Обойдя дом в третий раз, хозяин заходил в дверь, хозяйка должна была постелить ему под ноги безрукавку из овечьей шкуры. Диалог повторялся снова, после 
чего хозяин клал сноп в угол и все садились за стол. Аналогичный обычай существовал и в с. Лоевая Надворнянского р-на Ивано-Франковской обл.

В этом последнем диалоге, как и в диалоге из Красного, вопросы снова задаются мужчиной, стоящим на дворе, а ответы даются женщиной, стоящей внутри дома, или же всеми домашними. Возможно, такая структура связана с тем, что речь идет о поддержании чистоты и порядка, которое, как и куры, традиционно было одной из обязанностей женщины.

\section{Диалог, произносимый для уничтожения сорняков}

В с. Смольная Дрогобычского р-на Львовской обл. нами записан ритуальный диалог, произносившийся в сочельник для того, чтобы летом огород не зарастал бурьяном.

Информантка 1940 г. р. М. В. Шницер рассказала, как ее покойная мать, будучи девочкой, служила у пожилой хозяйки в соседнем селе Опака. В сочельник перед ужином хозяйка вышла на огород и заставила пойти с собой служанку:

[...] ну $\mid$ і вийшла баба на город $\mid$ і моя мати пішла $\mid$ ходем Аннуню зі мной $\mid$ будеш мене сі питати | ио я там їм | тай каже | баба так чвенькає | [МВШ изображает чавканье] |

а моя мати $\mid$ бабо $\mid$ ио ви там їсте $\mid$ ба та ӥм Аннуню і черевці $\mid$ імокрець | та усякій бурьӥнець | щоб не заростав город
[...] Ну, вышла баба в огород, и моя мать пошла. «Пошли, Аннуня, со мной! Будешь меня спрашивать, что я там ем». И, говорит, баба так чавкает.

А моя мать: «Баба, что Вы там едите?» — «Ну, так ем, Аннуня, и черевцы, и мокрец, и всякий бурьянец!» — чтобы не зарастал огород.

(Шницер М. В., 1940 г. р.; записано летом 2004 г.)

Сорняки имеют непосредственное отношение к огороду, а огород, как и всё, что с ним связано, относится к сфере женского труда; диалог происходит между двумя лицами женского пола, вопросы задает девочка (в силу возраста стоящая на более низкой ступени в гендерно-возрастной иерархии), отвечает женщина. Обе участницы диалога находятся в одном месте, на огороде, и не разделены границей между мирами. 


\section{ЗАКЛЮЧЕНИЕ}

1. В Карпатах до настоящего времени сохранилось большое количество ритуальных святочных диалогов; они представлены разными типами; для каждого можно определить ареалы распространения.

2. В диалогах важен не только текстуальный элемент, но и распределение ролей между участниками, а также мизансцены - положение участников относительно ключевых элементов пространства. В частности, в диалогах существенно расположение участников по отношению к границе между домом и внешним миром (порог, окно), которое помогает понять символические роли участников.

3. В диалоге существует иерархия ролей: вспомогательная роль у задающего вопросы, основная - у произносящего благословение/благопожелание. Диалоги бывают трехчастными (вопрос - ответ превращение ответа в благопожелание: Як на небі? - Ясно. - Так бы и на наших землях рясно; А щзо носите, діду? - Ношу полон! Дай боже би сте рік теперь щзасливо носили!) или двухчастными (вопрос - ответ, уже являющийся благопожеланием: Що там несеш? Хліб, сметану!). Зачастую вопрос задает лицо, находящееся на более низкой ступени в гендерно-возрастной иерархии, а отвечает (произносит благопожелание) лицо более высокого статуса. Несколько отличаются по структуре диалоги «запугивания» фруктовых деревьев, где зачастую отсутствует вопрос, а также диалоги относительно кур и некоторые диалоги, имеющие целью выведение мышей, где вопрос задается мужчиной женщине.

4. Святочные диалоги направлены на благословение хозяйственной деятельности и в своей совокупности охватывают практически все сферы традиционного хозяйства. В диалогах находит отражение половозрастная структура участников и гендерное распределение труда. В карпатской культуре (как и в других славянских культурах, ср. Бернштам 1988, Олсон, Адоньева 2016 и др.) существуют стандартные половозрастные сферы хозяйства: мужская сфера - поле (а также общее благополучие в крестьянском хозяйстве), женская сфера молочное хозяйство, огород, куры, одежда, поддержание чистоты 
и порядка. Как отмечено выше, в диалогах, призывающих благословение на определенные области хозяйства, в основной, благословляющей, роли может выступать либо стоящий снаружи хозяин, либо лицо, к обязанностям которого относится данная область хозяйства, а задает вопросы лицо более низкого статуса (хозяин - хозяйка, хозяйка - мальчик, женщина - девочка), хотя изредка бывает по-другому (так, если речь идет о традиционно женской сфере хозяйства, вопрос женщине может задаваться не только мальчиком, но - в редких случаях - и мужчиной). Таким образом, диалоги поддерживают традиционное гендерное разделение труда и - в основном - иерархию гендерно-возрастных групп. По материалу карпатских святочных диалогов можно заключить, что в этой культуре традиционно имелась и сфера хозяйства, где главными акторами являлись дети, - собирательство грибов и, может быть, орехов ${ }^{15}$. Поскольку дети представляют собой самый низкий уровень в традиционной иерархии деревенского общества, для них не находилось вопрошателя более низкого уровня, и они должны были задавать вопросы друг другу.

5. Анализ диалогов подтверждает предположение Проппа (1995: 45-66) о том, что благословление хозяйства в святочный период есть ритуализированная театрализация прихода с того света духов предков, которые могут одарить дом благосостоянием, если их задобрить, но могут и представлять собой опасность. Повторяющиеся элементы диалога через порог или через окно, обхода дома снаружи с благословениями, входа в дом благословляющего лица (и внос в дом снопа), отдания почестей и угощения (сноп ставят в красный угол и дают ему ложку, человека сажают за стол) подтверждают это предположение на нескольких разных уровнях.

6. Кроме святочного периода, диалоги в карпатской традиции встречаются в свадебной обрядности (например, сваты начинают с отцом невесты особый ритуализированный разговор о том, что пришли к ним в дом в погоне за куницей или что пришли покупать корову-нетель). Как и в святочных диалогах, в свадебных диалогах наличествуют две

15 В настоящее время собирание грибов и ягод осуществляется в основном женщинами. 
стороны, одна - домашние, другая - чужие, и ведутся переговоры с целью достигнуть договоренности между своими и чужими, олицетворяющими пришельцев с того света ${ }^{16}$. Таким образом, возможно, что ритуальные диалоги сохраняются именно в тех точках традиции, где они олицетворяют в драматической форме общение между этим и тем светом, миром живых и миром мертвых ${ }^{17}$.

7. Похоже, что кроме таких диалогов, которые можно считать самыми архаичными, существует ряд диалогов (при щупании кур; при собирании воображаемых грибов; возможно, при инсценируемом кусании камня для защиты от сплетен), где обе стороны обладают одинаковым статусом и не разделены границей внутреннего и внешнего пространства. Такие диалоги мы предлагаем считать либо происходящими из другого источника, либо вторичными, появившимися в результате желания распространить святочную продуцирующую и защитную магию на все сферы жизни. В них сохраняется структура диалога, но уже утрачено противопоставление благословляющего участника (внешнего) и участника, принимающего и истолковывающего благословение (внутреннего), а также гендерное противопоставление участников.

\section{ЛИтЕРАТУРА}

Бернштам 1988 - Бернштам T. А. Молодежь в обрядовой жизни общины ХІХ начала XX в.: половозрастной аспект традиционной культуры. Ленинград: Наука, 1988.

Будзан 1983 - Будзан А. Ф. Поселення, садиби, житло // Бойківщина: історико-етнографічне дослідження. Київ: Наукова думка, 1983. С. 159-166.

Будовская, Задоя - Будовская E. Э., Задоя К. С. Закарпатские рассказы о волке-оборотне. (В печати).

ЕСУМ - Етимологічний словник української мови. Київ, 1982-2012.

16 Выход замуж в патрилокальной культуре часто осознаётся как уход на чужбину навсегда, то есть как символическая смерть (ср. в культуре соседнего с карпатской территорией румынского Марамуреша — Kligman 1988: 77 и др.).

17 Диалоги, кроме этого, встречаются в других областях календарной обрядности (обряды на праздник Введения, на Пасху и др.). 
Гринченко - Гринченко Б. Словарь української мови. Зібрала редакція журнала «Кіевская Старина». Упорядкував, з додатком власного матеріялу, Борис Грінченко. Т. 1-4. Київ, 1907-1909.

Задоя 2015 - Задоя $K$. Народные наименования праздничных дней святочного цикла у населения Украинских Карпат // Відп. ред. П. Гриценко, Н. Хобзей. Діалектологічні студії. 10: Традиції та новаторство. Львів: Інститут українознавства ім. І. Крип'якевича НАНУ, 2015. С. 244-269.

Олсон, Адоньева 2016 - Олсон Л., Адоньева С. Традиция, трансгрессия, компромисс: Миры русской деревенской женщины. Москва: Новое литературное обозрение, 2016.

Пропп 1995 - Пропn В. Я. Русские аграрные праздники. СПб.: Азбука, 1995. РГАЛИ - Российский государственный архив литературы и искусства (Москва). СД - Славянские древности. Этнолингвистический словарь: в 5 т. / Под общей ред. Н. И. Толстого. М., 1995-2012. Т. 1. (А - Г). 1995; Т. 2. (Д- К). 1999; T. 3. (К - П). 2004; Т. 4. (П - С). 2009; Т. 5 (С - Я). 2012.

Толстой 1984 - Толстой Н. И. Фрагмент славянского язычества: архаический ритуал-диалог // Славянский и балканский фольклор: этногенетическая общность и типологические параллели. М.: Наука, 1984. С. 5-72.

Толстой 1993 - Толстой Н. И. Еще раз о славянском ритуальном диалоге // Славянское и балканское языкознание: Структура малых фольклорных текстов. М.: Наука, 1993. С. 82-110.

Топоров 2004 - Топоров В. Н. К реконструкции «загадочного» прототекста: о языке загадки // Oн же. Исследования по этимологии и семантике. В 3 тт. Том 1: Теория и некоторые частные ее приложения. М.: Языки славянских культур, 2004. С. 471-483.

Фасмер 2003 - Фасмер М. Этимологический словарь русского языка. М.: Астрель, 2003.

Kligman 1988 - Kligman G. The Wedding of the Dead: Ritual, Poetics, and Popular Culture in Transylvania. Berkeley: University of California Press, 1988.

Kira Sadoja (Düsseldorf), Elena Boudovskaia (Washington)

RitUAL DIALOGUES OF YULETIDE IN THE CARPATHIAN REGION OF UKRAINE

Abstract: Ritual dialogues have interested several prominent scholars of Slavic folklore as source for reconstruction of proto-Slavic ritual text structure. 
More recent studies of folklore have a different focus, studying the structure of Slavic societies reflected in folklore. This article introduces a number of ritual dialogues traditionally performed in villages in the Carpathian area of Western Ukraine around Yuletide, recorded by one of the authors between 1987 and 2018, and analyses the dialogues from both these points of view. A number of examined dialogues show specific structural patterns (question-answer-interpretation structure, the positions of the male performer outside the house, and the female performer, inside, etc.) agreeing with Propp's hypothesis about the Yuletide blessings of the house given by ancestral spirits coming from the otherworld in East Slavic culture, and with Toporov's hypothesis about Yuletide riddles performed in Indo-European culture to re-create world order at the time of winter solstice. Carpathian dialogs also turn out to reflect and corroborate the gender-age hierarchy of the traditional rural society.

Keywords: ritual dialogue, Yuletide, Western Ukraine, Carpathian area, gendered labor division

Note On THE AUTHORS:

Kira Sadoja is a researcher at the German Center of Slavic Studies (Düsseldorf). E-mail: kira.sadoja@hotmail.de

Elena Boudovskaia (PhD, MLIS) is a Teaching Professor of the Department of Slavic Languages at Georgetown University (Washington).

E-mail: eeb54@georgetown.edu

Резюме: Ритуальные диалоги привлекали внимание нескольких известных ученых в области славянского фольклора как источник для реконструкции структуры праславянского ритуального текста. Многие современные исследования традиционного фольклора имеют другую цель, а именно изучение отражения в фольклоре славянских традиционных обществ. Данная статья вводит в научный оборот ряд святочных ритуальных диалогов, бытующих в сельской местности в Украинских Карпатах и записанных одним из авторов в период между 1987 и 2018 гг., а также анализирует эти диалоги с обеих упомянутых точек зрения. Некоторые из диалогов обнаруживают специфическую структуру (последовательность вопрос-ответ-интерпретация, пространственное расположение участников - мужчина вне дома, женщина внутри дома и др.), 
что согласуется с предположением Проппа об отражении в святочном фольклоре представления о благословении дома духами предков, пришедших с того света, а также с предположением Топорова о загадках, используемых в древнеиндийском и - шире - индоевропейском фольклоре во время зимнего солнцестояния для восстановления мирового порядка. Кроме того, карпатские святочные диалоги отражают и подтверждают гендерно-возрастную иерархию традиционного сельского общества.

КлючевыЕ словА: ритуальный диалог, святки, Западная Украина, карпатский ареал, гендерное разделение труда

ОБ АВТОРАХ:

Задоя Кира Сергеевна - научный сотрудник Немецкого центра славистических исследований (Дюссельдорф).

E-mail: kira.sadoja@hotmail.de

Будовская Елена Эдуардовна - преподаватель отделения славянских языков Джорджтаунского университета (Вашингтон).

E-mail: eeb54@georgetown.edu 